\title{
Role of Carpenter Bee (Xylocopa fenestrata) Pollination on Fruit and Seed Yield of Ridge Gourd, Luffa acutangula $\mathrm{L}$.
}

\author{
Prem Prakash Gautam* and Neeraj Kumar \\ Department of Entomology, Dr. Rajendra Prasad Central Agricultural University Pusa, \\ Samastipur (Bihar) 848125, India \\ *Corresponding author
}

\section{A B S T R A C T}

\begin{tabular}{|l|}
\hline Ke y w o r d s \\
Xylocopa \\
fenestrata, \\
Pollination effect, \\
Ridge gourd
\end{tabular}

The field experiments were conducted at the University Apiary, Dr. Rajendra Prasad Central Agricultural University Pusa, Samastipur (Bihar) during the Kharif season to document the production of fruits and seeds of ridge gourd increased significantly by pollination of Xylocopa fenestrata. The aim of this research was to study the pollination of ridge gourd (Luffa acutangula), to determine the effect of the visits on flowers per plant, fruit set, fruits per plant, fruit size, fruit weight, number of seeds, weight of 100 seed and seed yield. The obtained results showed that the open pollination (OP) treatment produced the highest fruit set per cent, number of fruits per plant, fruit weight, fruit yield followed by Xylocopa pollination, viz. $\mathrm{XP}_{3}, \mathrm{XP}_{2}$ and $\mathrm{XP}_{1}$, whereas lowest in pollination exclusion (PE). The result reflected that there was $36.80 \%$ increased in fruit yield in OP while, it was $34.50 \%$ in $\mathrm{XP}_{3}, 25.30 \%$ in $\mathrm{XP}_{2}$ and $22.20 \%$ in $\mathrm{XP}_{1}$ treatment over pollination exclusion. Similarly, the highest number of seed per fruit, weight of 100 seed was found maximum in OP followed by $\mathrm{XP}_{3}, \mathrm{XP}_{2}, \mathrm{XP}_{1}$ and was lowest in PE treatment. The percentage increment in seed yield was recorded highest in the $\mathrm{OP}(70.00 \%)$ followed by $\mathrm{XP}_{3}(50.00 \%), \mathrm{XP}_{2}$ $(30.00 \%)$ and $\mathrm{XP}_{1}(10.00 \%)$ over PE treatment. The insect pollinators play significant role in pollinating ridge gourd flowers and enhancing yield of crop.

\section{Introduction}

Insect pollinators play a crucial role in effecting optimum pollination of many crops thus contributing to both increased quantity and quality. Their essentiality is more significant in crops like Cucurbits, which are monoecious (male and female flowers are borne at different positions on the same plant). Ridge gourd (Luffa acutangula L.) is one of the widely cultivated vegetable crops in Bihar. Considering the importance of pollination in the establishment and production of fruits in various crops and the reduction in the diversity and abundance of pollinating agents, it is necessary to evaluate the need of controlled pollination of crops dependent on pollinating agents (Fonseca et al., 2006). The insects of family Apidae like Carpenter bee (Xylocopa fenestrata) are the most reliable agents for pollination of cucurbitaceous crops. Unlike honeybees, they do not form colonies and live solitarily. Among the solitary bees, the Carpenter bees Xylocopa fenestrata are the commonest species in Bihar. Carpenter bees possess several advantages as potential crop 
pollinators compared to other non Apis bees. They are expected to contribute most to crop pollination when honey bees are ineffective. For example, the high thermoregulatory ability of carpenter bees enables them to forage at higher ambient temperatures than honey bees. This makes them suitable pollinators in hot areas and in hot microclimates, such as in polyhouse. The crepuscular and nocturnal activity of some species may also allow them to pollinate night-flowering crops, which are not visited by honey bees.

The objective of this study was to evaluate pollination in ridge gourd to determine the resultant effects in terms of fruit and seed production.

\section{Materials and Methods}

To study the impact of Xylocopa fenestrata pollination on ridge gourd flowers, crop was grown with recommended agronomic packages and practices at University Apiary, Dr. Rajendra Prasad Central Agricultural University Pusa, Samastipur (Bihar) during the Kharif season of 2016-17. The experiment was laid out with 5 treatments with 4 replications in RBD as per details given below:

$\mathrm{T}_{1}$ - Open to all pollinators $(\mathrm{OP})$

$\mathrm{T}_{2}$ - Pollinator exclusion (PE)

$\mathrm{T}_{3}$ - Caged with Xylocopa (Bamboo with 1 nest)

$\mathrm{T}_{4}$ - Caged with Xylocopa (Bamboo with 2 nest)

$\mathrm{T}_{5}$. Caged with Xylocopa (Bamboo with 3 nest)

The pollination exclusion treatment and carpenter bee, Xylocopa fenestrata pollinated crop were covered with nylon net $(10 \times 10 \times$ $10 \mathrm{ft}$ ) of suitable mesh size to prevent visitation of other pollinators on the crop. The observations were recorded on the following parameters, viz. flowers per plant (No.), fruit set (\%), fruits per plant (No.), fruit weight (g), fruit length $(\mathrm{cm})$, fruit girth $(\mathrm{cm})$, fruit yield (q/ha), No. of seed/fruit, 100-seed weight (g) and Seed yield (q/ha).

\section{Results and Discussion}

Effect of Xylocopa fenestrata pollination on fruit yield and their characteristics of ridge gourd

The studies on effect of Xylocopa fenestrata pollination on fruit yield and their characteristics of ridge gourd are presented in Table 1 and Figure 1. The maximum number of flower per plant was recorded in open pollination (23.50) followed by Xylocopa pollination $\mathrm{XP}_{3}$ (22.50), $\mathrm{XP}_{2}(22.00), \mathrm{XP}_{1}$ (21.80) and minimum in PE (20.00) crop having non-significant variations among different treatments. The treatment open pollination produced the maximum number of fruits per plant $(78.70 \%)$ followed by $\mathrm{XP}_{3}$, $\mathrm{XP}_{2}$ and $\mathrm{XP}_{1}(72.20 \%, 63.60 \%$ and $52.70 \%$, respectively) and the minimum fruit set was observed being 50.00 per cent in pollinator exclusion (PE) treatment.

The number of fruits per plant was recorded $18.5,16.2,14.0,11.5$ and 10.0 in $\mathrm{OP}, \mathrm{XP}_{3}$, $\mathrm{XP}_{2}, \mathrm{XP}_{1}$ and $\mathrm{PE}$, respectively. It was highest in $\mathrm{OP}$ followed by $\mathrm{XP}_{3}, \mathrm{XP}_{2}, \mathrm{XP}_{1}$ and was lowest in case of PE treatment. The average fruit weight was obtained maximum with $\mathrm{OP}$ treatment, i.e. $85.60 \mathrm{~g}$ which was significantly higher than the mean fruit weight in other treatments, i.e. $80.50 \mathrm{~g}, 74.30 \mathrm{~g}$ and $70.10 \mathrm{~g}$ under $\mathrm{XP}_{3}, \mathrm{XP}_{2}$ and $\mathrm{XP}_{1}$, respectively and the minimum fruit weight was recorded under (PE) treatment being $51.80 \mathrm{~g}$. The observation indicated that there was no significant 
difference in fruit length and fruit girth of ridge gourd in different treatments. The average fruit yield was recorded maximum in OP being $82.30 \mathrm{q} / \mathrm{ha}$, followed by $\mathrm{XP}_{3}, \mathrm{XP}_{2}$ and $\mathrm{XP}_{1}(81.00 \mathrm{q} / \mathrm{ha}, 75.50 \mathrm{q} / \mathrm{ha}$ and 73.60 $\mathrm{q} /$ ha, respectively). Minimum fruit yield of ridge gourd was recorded under the $\mathrm{PE}$ treatment being $60.20 \mathrm{q} / \mathrm{ha}$. The per cent increase in fruit yield was $36.80 \%, 34.50 \%$, $25.30 \%$ and $22.20 \%$ increase in $\mathrm{OP}, \mathrm{XP}_{3}, \mathrm{XP}_{2}$ and $\mathrm{XP}_{1}$, respectively over $\mathrm{PE}$.

The results of yield parameters in ridge gourd revealed that pollination is essential for improving yield and quality of ridge gourd. The significant increase was found in the parameters, viz. fruit set, fruit per plant, fruit weight and fruit yield, while number of flowers per plant, fruit length and fruit girth were found non-significant. The data showed that all the parameters recorded were highest in open pollination (OP) treatment in comparison to Xylocopa pollination $\left(\mathrm{XP}_{3}, \mathrm{XP}_{2}\right.$ and $\mathrm{XP}_{1}$ ) treatment. This might be due to fact that in the OP treatment, pollination occurred through the large number of insect pollinators including Xylocopa bee species while caged treatments were deprived of other insect pollinators. The OP treatment showed superiority in all the parameters studied over $\mathrm{XP}_{3}, \mathrm{XP}_{2}, \mathrm{XP}_{1}$ and $\mathrm{PE}$ treatments might be due to visit of large number of pollinator species leading to increase in pollination of crop. But when $\mathrm{XP}_{1}, \mathrm{XP}_{2}$ and $\mathrm{XP}_{3}$ were considered separately, it also showed superiority over PE treatment in all the parameters discussed above indicating that Xylocopa bees play a significant role in pollinating ridge gourd and improving yield parameters.

These results are in agreement with finding of earlier workers. Sarwar et al., (2008) reported similar results in cucumber. They observed highest fruit set per cent, number of fruit per plant and yield $(\mathrm{q} / \mathrm{ha})$ in open pollination followed by bee pollination while lowest in control treatment. Sajjanar et al., (2004) recorded higher fruit set $(81.43 \%)$ in open pollination crop and with honey bee pollination in caged conditions $(75.00 \%)$ and lowest being (10.71\%) under control. Gogoi et al., (2014) reported significant impact of $X$. fenestrata pollination on yield and fruit characteristics of ridge gourd. They found that in Xylocopa pollination $\left(\mathrm{XP}_{3}\right)$ treatments the highest number of fruits/plant was $17.81 \pm 0.325$ followed by $16.78 \pm 0.58$ in open pollination and lowest $(5.22 \pm 0.41)$ in pollination exclusion treatment. Similarly, the fruit set in Xylocopa pollination $\left(\mathrm{XP}_{3}\right)$ treatment was observed to be $34.91 \%$ as against $32.98 \%$ and $10.31 \%$ in open and pollinator exclusion treatments. Cervancia and Bergonia (2017) found that the fruit set of bee and open pollinated crop was significantly higher than non-pollinated cucumber crop.

\section{Effect of Xylocopa fenestrata pollination on seed yield of ridge gourd}

The data with respect to the effect of different mode of pollination on number of seed per fruit, 100-seed weight $(\mathrm{g})$, seed yield (q/ha) and seed yield increase over PE $(\%)$ is depicted in Table 2 and Figure 2. The mean number of seeds per fruit was recorded highest in OP treatment (27.00) which was followed by $\mathrm{XP}_{3}, \mathrm{XP}_{2}$ and $\mathrm{XP}_{1}(25.50,24.00$ and 22.20), respectively and the lowest was recorded in PE treatment (19.50). The weight of 100-seeds was recorded $15.2 \mathrm{~g}, 13.1 \mathrm{~g}, 12.5$ $\mathrm{g}, 11.0 \mathrm{~g}$ and $9.0 \mathrm{~g}$ in $\mathrm{OP}, \mathrm{XP}_{3}, \mathrm{XP}_{2}, \mathrm{XP}_{1}$ and $\mathrm{PE}$ respectively which was significantly different. It was highest in OP followed by $\mathrm{XP}_{3}, \mathrm{XP}_{2}, \mathrm{XP}_{1}$ and was least in case of $\mathrm{PE}$ treatment. The average seed yield was recorded maximum in OP treatment $(1.7 \mathrm{q} / \mathrm{ha})$, followed by $\mathrm{XP}_{3}, \mathrm{XP}_{2}$ and $\mathrm{XP}_{1}(1.5 \mathrm{q} / \mathrm{ha}, 1.3$ $\mathrm{q} / \mathrm{ha}$ and $1.1 \mathrm{q} / \mathrm{ha}$ ), respectively and minimum was recorded under the PE treatment (1.0 q/ha). 
Table.1 Effect of Xylocopa fenestrata pollination on quantitative and qualitative parameters on fruit yield of ridge gourd

\begin{tabular}{|c|c|c|c|c|c|c|c|c|}
\hline Treatments & $\begin{array}{c}\text { Flower/ } \\
\text { plant } \\
\text { (No.) }\end{array}$ & $\begin{array}{c}\text { Fruit } \\
\text { set } \\
(\%)\end{array}$ & $\begin{array}{l}\text { Fruit/ plant } \\
\qquad \text { (No.) }\end{array}$ & $\begin{array}{l}\text { Fruit } \\
\text { weight } \\
\text { (g) }\end{array}$ & $\begin{array}{c}\text { Fruit } \\
\text { length } \\
(\mathrm{cm})\end{array}$ & $\begin{array}{l}\text { Fruit } \\
\text { girth } \\
\text { (cm) }\end{array}$ & $\begin{array}{l}\text { Fruit } \\
\text { yield } \\
\text { (q/ha) }\end{array}$ & $\begin{array}{c}\text { Fruit yield increase } \\
\text { over PE }(\%)\end{array}$ \\
\hline $\begin{array}{c}\text { Pollinator exclusion } \\
\text { (PE) }\end{array}$ & 20.00 & 50.00 & 10.00 & 51.80 & 13.00 & 9.50 & 60.20 & - \\
\hline $\begin{array}{c}\text { Caged with } \\
\text { Xylocopa }\left(\mathrm{XP}_{1}\right)\end{array}$ & 21.80 & 52.70 & 11.50 & 70.10 & 14.20 & 10.20 & 73.60 & 22.20 \\
\hline $\begin{array}{c}\text { Caged with } \\
\text { Xylocopa }\left(\mathbf{X P}_{2}\right)\end{array}$ & 22.00 & 63.60 & 14.00 & 74.30 & 14.80 & 10.50 & 75.50 & 25.30 \\
\hline $\begin{array}{c}\text { Caged with } \\
\text { Xylocopa }\left(\mathrm{XP}_{3}\right)\end{array}$ & 22.50 & 72.20 & 16.20 & 80.50 & 15.20 & 10.70 & 81.00 & 34.50 \\
\hline $\begin{array}{l}\text { Open pollinators } \\
(\mathrm{OP})\end{array}$ & 23.50 & 78.70 & 18.50 & 85.60 & 16.00 & 11.50 & 82.30 & 36.80 \\
\hline S Em $( \pm)$ & - & 1.17 & 0.89 & 1.55 & - & - & 2.78 & - \\
\hline $\mathrm{CD}(\mathrm{P}=0.05)$ & N.S. & 3.64 & 2.77 & 4.84 & N.S. & N.S. & 8.67 & - \\
\hline
\end{tabular}

Table.2 Effect of Xylocopa fenestrata pollination on seed yield of ridge gourd

\begin{tabular}{|c|c|c|c|c|}
\hline Treatments & No. of seed/fruit & 100-Seed weight(g) & Seed yield (q/ha) & Seed yield increase over PE (\%) \\
\hline Pollinator exclusion (PE) & 19.50 & 9.00 & 1.00 & - \\
\hline $\begin{array}{c}\text { Caged with Xylocopa } \\
\left(\mathbf{X P}_{1}\right)\end{array}$ & 22.20 & 11.00 & 1.10 & 10.00 \\
\hline $\begin{array}{c}\text { Caged with Xylocopa } \\
\left(\mathrm{XP}_{2}\right)\end{array}$ & 24.00 & 12.50 & 1.30 & 30.00 \\
\hline $\begin{array}{c}\text { Caged with Xylocopa } \\
\left(\mathbf{X P}_{3}\right)\end{array}$ & 25.50 & 13.10 & 1.50 & 50.00 \\
\hline Open pollinators (OP) & 27.00 & 15.20 & 1.70 & 70.00 \\
\hline $\operatorname{S~Em~}( \pm)$ & 0.75 & 0.99 & 0.04 & - \\
\hline $\mathrm{CD}(\mathrm{P}=\mathbf{0 . 0 5})$ & 2.35 & 3.09 & 0.15 & - \\
\hline
\end{tabular}


Fig.1 Effect of Xylocopa fenestrata pollination on fruit yield of ridge gourd
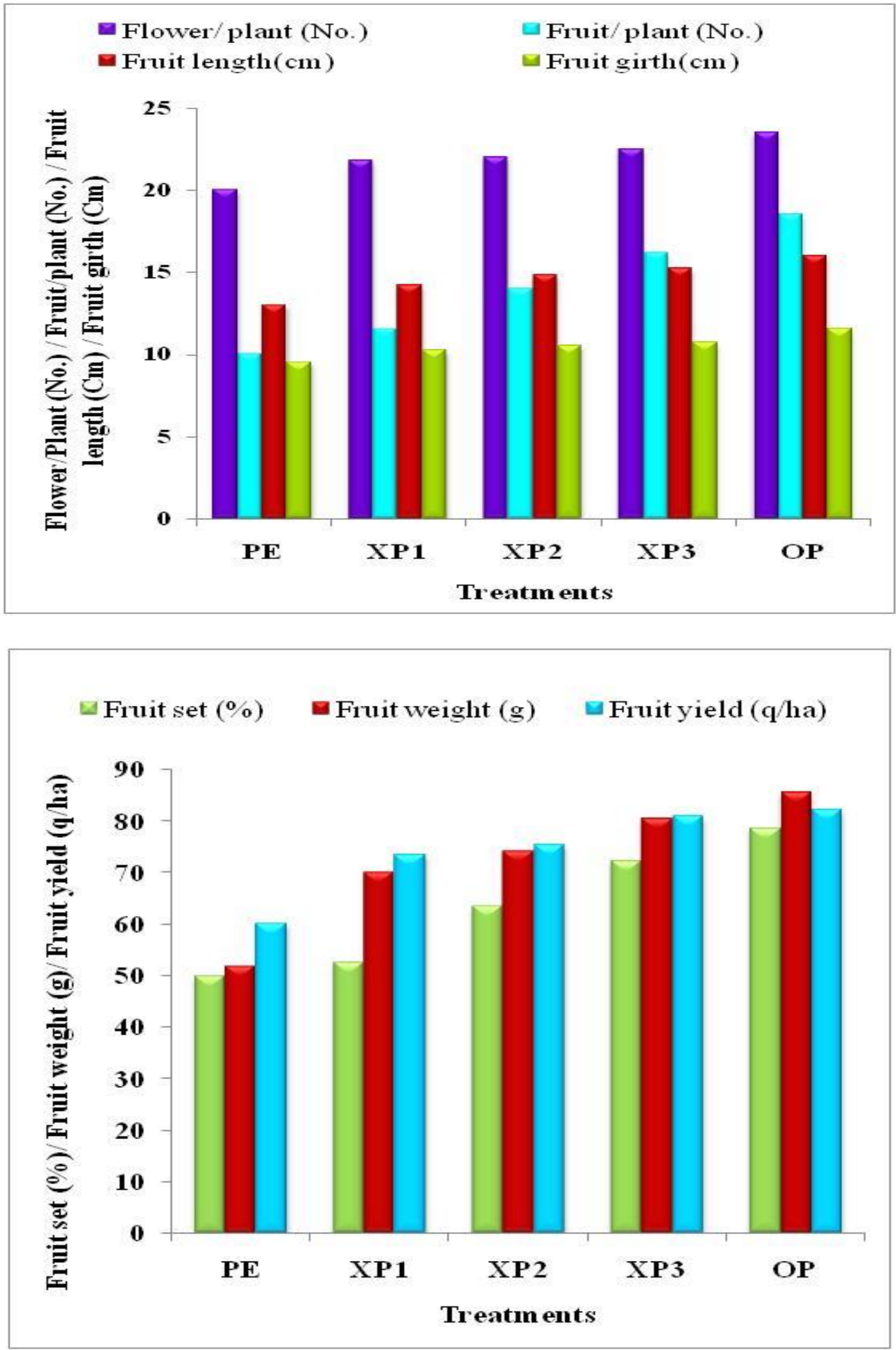
Fig.2 Effect of Xylocopa fenestrata pollination on seed yield of ridge gourd

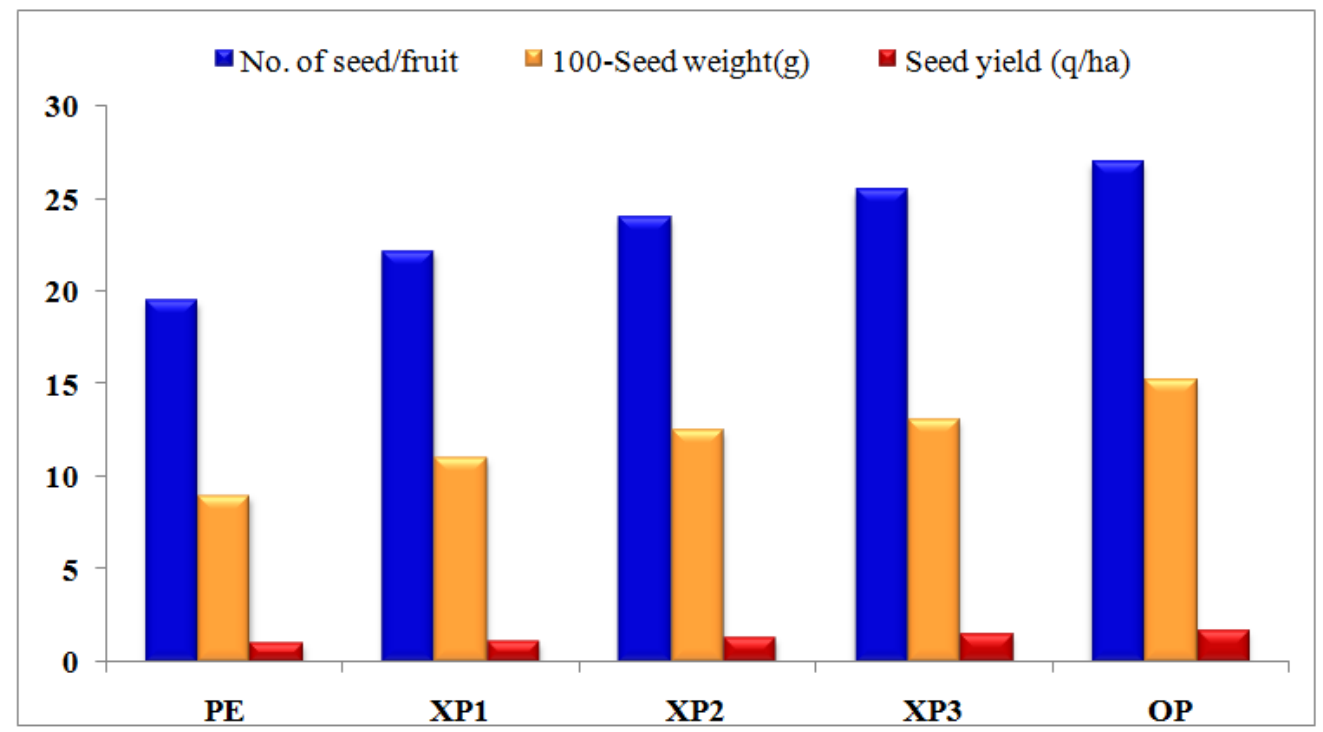

The per cent increase in seed yield were recorded $70.0 \%, 50.0 \%, 30 \%$ and $10.0 \%$ increase in $\mathrm{OP}, \quad \mathrm{XP}_{3}, \quad \mathrm{XP}_{2}$ and $\mathrm{XP}_{1}$ respectively over $\mathrm{PE}$.

The results of above parameters indicated that insect pollination in ridge gourd has significant impact on seed yield. The highest seed yield parameters were recorded in OP treatment, which might be due to fact that visit of large number of insect pollinators. OP treatment showed significantly superior in all the above parameters studied over other treatments. The caged treatments with Xylocopa $\mathrm{XP}_{1}, \mathrm{XP}_{2}$ and $\mathrm{XP}_{3}$ also showed superiority over $\mathrm{PE}$ treatment in all the parameters recorded. It indicated that Xylocopa bees were helpful in pollinating ridge gourd and increased yield over selfpollinated crop. In the PE treatment, there was no insect pollinator species and it was selfpollinated that resulted lowest seed yield.

The present findings were in accordance with the findings of earlier workers who previously reported increase in seed yield due to insect pollination in different crops. Kingha et al.,
(2012) reported that the mean number of seeds per pod is concerned in $P$. vulgaris visited exclusively by $X$. olivacea and maximum mean numbers of seeds per pod in opened flowers were noticed $(19.38 \%)$ as compared to bagged flowers. Thakur and Rana (2008) reported that the weight of fruits (1184.5 g), number of seeds per fruit (472.8), fruit size $(28.8 \mathrm{~cm})$ and weight of 1000 -seeds $(29.14 \mathrm{~g})$ was highest in honey bee pollinated crop as compared to other modes of pollination in cucumber. Suhail et al., (2001) reported that the foraging of honey bee resulted in maximum yield $(352.7 \mathrm{~kg} / \mathrm{ha})$, 1000 grain weight $(27.12 \mathrm{~g})$ and germination $(90.33 \%)$ indicating that the use of honey bee colonies increased the quality and quantity of cucumber seed crop significantly. Taha and Bayoumi (2009) reported that in summer seed watermelon, non-pollinated plants did not produce yield, while open pollinated produced $2436.93 \mathrm{~kg}$ seed per hectare. The yield increase in the insect pollinated crop might be due to the fact that amount of pollen deposited on stigmas by insect pollinators increased the number of successful fertilized ovules in the flower which led to higher seed 
set, while in the crop deprived of insect pollinators only self-pollination occur resulting in poor yield. Therefore, the augmentation of insect pollinators especially Xylocopa in ridge gourd will give higher seed yield due to better pollination of flowers.

These studies indicated that Xylocopa fenestrata was the most efficient pollinator. The quantitative parameters, viz. fruit set, fruit per plant, fruit weight, fruit yield and seed yield were significantly influenced by Xylocopa fenestrata pollination. The per cent increase in fruit yield in Xylocopa pollinated crop over pollination excluded crop varied from 22.20 to 36.80 per cent while seed yield varied from 10 to 70 per cent. It is therefore concluded that Xylocopa fenestrata pollination gives best results and hence should be exploited to enhance the yield and quality of fruits.

\section{References}

Cervancia, C.R. and Bergonia, E.A. (2017). Insect pollination of cucumber (Cucumis sativus L.) in the Philippines. International Society for Horticultural Science, Article no. 288(43): 1-4.

Fonseca, V.L.I., Saraiva, A.M. and Dejong, D. (2006). Bee as pollinators in Brazil. Ribeirao Preto: Holos, 112.

Gogoi, J., Rahman, A., Rajkumari, P. and Saikia, J. (2014). Diversity of insect foragers and effect of carpenter bee, Xylocopa fenestrata $\mathrm{F}$. on pollination of ridge gourd. Indian Journal of Entomology, 76(4): 325-328.
Kingha, B.M.T., Fohouo, F.T., Ngakou, A and Bruckner, D. (2012). Foraging and pollination activities of Xylocopa olivacea (Hymenoptera, Apidae) on Phaseolus vulgaris (Fabaceae) flowers at Dang (Ngaoundere-Cameroon). Journal of Agricultural Extension and Rural Development, 4(6): 330-339.

Sajjanar, S.M., Kuberappa, G.C. and Prabhuswamy, H.P. (2004). Insect visitors of cucumber (Cucumis sativus L.) and the role of honey bee, Apis cerana F. in its pollination. Pest management and Economic Entomology, 12(1): 23-31.

Sarwar, G., Aslam, M., Munawar, M.S., Raja, S. and Mahmood, R. (2008). Effect of honey bee (Apis mellifera L.) pollination on fruit setting and yield of cucumber (Cucumis sativus L.). Pak. Entomol., 30(2): 185-191.

Suhail, A., Abdin, Z., Iqbal, J., Iqbal, M., Weseem, U., Shahid, R.N. and Haq, I. (2001). Insecticidal mortality and pollination role of honey bee (Apis mellifera L.) on cucumber (Cucumis sativus L.) crop. International Journal of Agriculture and Biology, 3(4): 501502.

Taha, E.A. and Bayoumi, Y.A. (2009). The value of honey bees (Apis mellifera, L.) as pollinators of summer seed watermelon (Citrullus lanatus colothynthoides L.) in Egypt. Acta Biologica Szegediensis, 53(1): 33-37.

Thakur, M. and Rana, R.S. (2008). Studies on the role of insect pollination on cucumber yield. Pest Technology. Global Science Books, 2(2): 130-133.

\section{How to cite this article:}

Prem Prakash Gautam and Neeraj Kumar. 2018. Role of Carpenter Bee (Xylocopa fenestrata) Pollination on Fruit and Seed Yield of Ridge Gourd, Luffa acutangula L. Int.J.Curr.Microbiol.App.Sci. 7(03): 3322-3328. doi: https://doi.org/10.20546/ijcmas.2018.703.383 